\title{
Evaluation and Influence on the Development Strategy of the Maritime Silk Road
}

\author{
Ning Zhang \\ College of Information Science and Engineering \\ Shandong University of Science and Technology, \\ Qingdao, Shandong, China \\ zning@sdust.edu.cn
}

\author{
Jing Tang \\ College of Information Science and Engineering \\ Shandong University of Science and Technology, \\ Qingdao, Shandong, China \\ 493117148@qq.com
}

\begin{abstract}
This paper studies the economic and trade of Maritime Silk Road from the perspective of trade facilitation. Through the establishment of multiple linear regression model and trade gravity model, the paper makes a quantitative evaluation on the impact of the Silk Road on the sea. The value of trade facilitation is constantly improving. From this we give the suggestion that in the domestic resources to improve the range of 5 points of trade facilitation, if the limited resources, it should be based on the relevant calculation, determine which trade facilitation of the contribution of the sub index, priority to the use of resources in a greater impact on the trade facilitation of points. Specifically, governments should increase the investment in the infrastructure of trade facilitation, not only the construction of hardware facilities, but also the investment of software facilities.

Keywords: Maritime Silk Road; Strategic Policy; Multiple Linear Regression Model; Trade Gravity Model; Evaluation and Impact; SPSS Analysis
\end{abstract}

\section{INTRODUCTION}

In October 2013, during his visit to the countries of Southeast Asia. Chairman xi speech, said Southeast Asia since ancient times is the important hub "Marine silk road". So far, China's strategic plan of "One Belt And One Road" is ripe, the Silk Road economic belt and the maritime silk road in the 21 st century. [1] [2] [3]

The maritime Silk Road in the 21 st century should be a global network based on trade, also is the international trade network. Tariff has deep cuts in the countries all over the world, how to use trade facilitation to promote trade both sides of the economic development, it is theoretical issues of common concern to all countries in the world. [9] [10] As a result, the new sea route of the silk road is a dynamic rather than static, not only covers China and Southeast Asia, South Asia and west Asia and East Africa, should also be extended to Australia, and North America, and through this international trade network reflect the economic and trade relations between China and the countries of the world trade network.

Construction and development of the Marine silk road, should look at the goods trade as the main means, make good use of the Chinese government to set up the China-Asian maritime cooperation fund, based on the sea, developing good Marine cooperation partnership, deepening and extension of the ChinaAsian free trade area, promote regional economic and security economic and security.

\section{THE DESCRIPTION OF THE}

\section{PROBLEM}

In our paper, we will analyze the following contents:

1. In this paper, we will refer to the relevant information. And Select the most important factor in the maritime Silk Road - economic trade, as the focus of this paper and analyze the relevant indicators. Based on the multiple linear regression model and the trade gravity model, we study the development strategy of the Silk Road on the sea.

\section{THE HYPOTHESIS OF PROBLEM}

We assume that:

1. All of the countries have typical representative, and they have linked with Maritime Silk Road.

2. As mentioned in this article, the distance between countries, by default, is replaced by the distance between the capitals of the two countries.

\section{THE DESCRIPTION OF SYMBOL}

Table 1. The Description and Explanation of Symbol in this Paper

\begin{tabular}{|c|c|}
\hline Symbol & Description and Explanation \\
\hline$C C_{j}$ & Comprehensive index of trade facilitation. \\
\hline$P O L I C Y_{i j}$ & $\begin{array}{l}\text { Bilateral trade environment, if the member state } \\
\text { is the Maritime Silk Road along the country, the } \\
\text { value is } 1 \text {, otherwise it is } 0 \text {. }\end{array}$ \\
\hline$T A R_{j}$ & $\begin{array}{l}\text { The average tariff of Country } \mathrm{j} \text {, it's the average } \\
\text { value of the tariff rate for all trade goods. }\end{array}$ \\
\hline$B O R_{i j}$ & $\begin{array}{l}B O R_{i j} \text { is a dummy variable that Partner } \mathrm{j} \text { and } \\
\text { Chinese bordering the territory when the value } \\
\text { is } 1 \text {, otherwise it is } 0 \text {. }\end{array}$ \\
\hline$Y_{i}, Y_{\max }$ & $\begin{array}{l}Y_{i} \text { is the original data, } Y_{\max } \text { is the maximum value } \\
\text { of the index. }\end{array}$ \\
\hline$Z_{i}$ & $\frac{Y_{i}}{Y_{\max }}=Z_{i}, Z_{i}$ is standardized data after treatment. \\
\hline Trade $_{j}$ & Trade volume between Country i and j. \\
\hline
\end{tabular}




\begin{tabular}{ll}
\hline Symbol & \multicolumn{1}{c}{ Description and Explanation } \\
\hline$G D P_{i}$ & Gross Domestic Product of Country i. \\
$G D P_{j}$ & Gross Domestic Product of Country j. \\
$P G D P_{i}$ & $\begin{array}{l}\text { Per capita Gross Domestic Product of Country } \\
\text { i. }\end{array}$ \\
$P G D P_{j}$ & $\begin{array}{l}\text { Per capita Gross Domestic Product of Country } \\
J L_{i j}\end{array}$ \\
\hline
\end{tabular}

\section{MODELING}

\subsection{Modeling of Trade Evaluation Model in Maritime Silk Road}

In recent years, with the dynamic social network analysis, we can find complex covert network, and through a series of algorithms to estimates people who have been in contact with terrorism individuals risk index, in order to determine a key figure what we need. And then take corresponding measures to solve it. [4] [5]

\subsubsection{Theory Building}

Summarized above measure of trade facilitation in the literature review has the following categories: 1. Port Efficiency (KA) 2 . Customs environment 3. Regulatory and institutional environment 4. Marketing Factors 5. Infrastructure.

In this paper, based on the above five indexes to study China and trade between the countries along the maritime silk route to measure the level of trade facilitation, and then through the contrast can be concluded that the maritime silk road trade development strategy is put forward for China. Us to the five indicators, digital processing, multiple linear regression analysis by SPSS can get all kinds of factor value, the greater the number, shows that the index of the greater the degree of influence on trade facilitation.

\section{Port Efficiency (KA)}

Port efficiency refers to the efficiency of the operations of ports, airports and other infrastructure, the index of coefficient value is higher, said the airport, the port cargo throughput and cargo loading and unloading, handling, storage and the higher the efficiency. Specific indicators include Quality of port infrastructure (P1) and Quality of air transport infrastructure (P2)

\section{Customs environment (TE)}

The customs environment refers to the cost of the cost and time needed for customs clearance, and under the customs law and regulations, the size of the rent-seeking space, specific include:

(1) Irregular payments and bribes (C1). The indicator to measure whether in order to obtain the relevant import and export license to the customs personnel for rent-seeking and the resultant costs or is the enterprise of planned spending. 1 for irregular payments, often values 7 said had never happened in the abnormal phenomena of payment.

(2) Ethics and corruption (C2). People in the field of the indicators is related to a country customs corruption degree of evaluation, the numerical value range of fluctuation represent different meanings. 1 minute, serious corruption, 7 points, said there is no corruption, very honest.

(3) Burden of customs procedures (C3). The customs declaration formalities trival degree is not the same. 1 minute said customs formalities is extremely complicated and 7 points said entry is simple and efficient.

(4) Degree of customer orientation (C4). The indicator to measure a country's customs overall service capacity, the higher the score represents the stronger service ability, the highest is divided into seven points.

\section{Regulatory and institutional environment (LE)}

A country's laws and regulations and the system more transparent, the smaller the rent-seeking space, import and export business, the available in a more transparent society under the rule of law for international trade.

(1) Transparency of government policymaking (R1).The higher the score the higher the transparency of the on behalf of the country's law. The highest is divided into seven points.

(2) Efficiency of legal framework in settling disputes (R2).The higher the score on behalf of the country's laws and regulations are strictly enforced. 1 minute means the country did not perform the relevant laws and regulations.

\section{Extent of marketing (DZ)}

The coming of the era of big data, making the number of the marketing factors are increases. Companies use different marketing factors, can be more convenient to keep in close contact with customers, suppliers, customs, reduce the risk caused by information asymmetry.

\section{Infrastructure (TC)}

Infrastructure of transportation problem is a measure of export enterprises for the country's logistics department of transport and logistics ability indicators. Specific indicators are as follows:

(1)Quality of roads (A1).The higher the score, the smaller the transportation time and cost.

(2)Quality of railroad infrastructure (A2).The higher the score, the smaller the transportation time and cost.

Table 2. Trade facilitation measure

\begin{tabular}{ccc}
\hline Level indicators & Secondary indicators & $\begin{array}{c}\text { Three } \\
\text { indicators }\end{array}$ \\
\hline $\begin{array}{c}\text { Port } \\
\text { Efficiency(KA) }\end{array}$ & $\begin{array}{c}\text { Quality of port } \\
\text { infrastructure(P1) } \\
\text { Quality of air transport } \\
\text { infrastructure(P2) }\end{array}$ & $1-7$ \\
& $\begin{array}{c}\text { Irregular payments and } \\
\text { bribes(C1) } \\
\text { Ethics and } \\
\text { Customs }\end{array}$ & $1-7$ \\
environment(TE) & $\begin{array}{c}\text { Burden of customs } \\
\text { procedures(C3) } \\
\text { Degree of customer } \\
\text { orientation(C4) }\end{array}$ & $1-7$ \\
& $\begin{array}{c}\text { Transparency of } \\
\text { government } \\
\text { policymaking(R1) } \\
\text { Efficiency of legal } \\
\text { Regulatory and } \\
\text { institutional } \\
\text { environment(LE) }\end{array}$ & $1-7$ \\
& $\begin{array}{c}\text { framework in settling } \\
\text { disputes(R2) }\end{array}$ & $1-7$ \\
\hline
\end{tabular}




\begin{tabular}{ccc}
\hline Level indicators & Secondary indicators & $\begin{array}{c}\text { Three } \\
\text { indicators }\end{array}$ \\
\hline $\begin{array}{c}\text { Extent of } \\
\text { marketing (DZ) }\end{array}$ & $\begin{array}{c}\text { Extent of } \\
\text { marketing(DZ) }\end{array}$ & $1-7$ \\
\hline Infrastructure(TC) & $\begin{array}{c}\text { Quality of roads(A1) } \\
\text { Quality of railroad } \\
\text { infrastructure(A2) }\end{array}$ & $1-7$ \\
\hline
\end{tabular}

Note: Data from the 2015 "Global Competitiveness Report" http://www3.weforum.org/docs/WEF_GlobalCompetitiveness Report_2014-15.pdf

\subsubsection{Required Data for Standardization}

Because the measure index of trade facilitation is taken in the case of time range is not unified, the data are not comparable. As a result, the need for data processing, standardization of data obtained, to use, specific USES the following practices, remember to take a secondary index, on behalf of the original raw data, on behalf of the index can achieve maximum value, and is standardized processing of data, finally will be all kinds of secondary standardization index level resulting from the weighted average index. [6] [7] [8]

Port Efficiency $(\mathrm{KA})=($ Quality of port infrastructure $(\mathrm{P} 1)$ +Quality of air transport infrastructure (P2))/2

Customs environment $(\mathrm{TE})=($ Irregular payments and bribes $(\mathrm{C} 1)+$ Ethics and corruption $(\mathrm{C} 2)+$ Burden of customs procedures $(\mathrm{C} 3)+$ Degree of customer orientation $(\mathrm{C} 4)) / 4$

Regulatory and institutional environment $(\mathrm{LE})=($ Transparency of government policymaking (R1) +Efficiency of legal framework in settling disputes (R2))/2

Infrastructure $(\mathrm{TC})=($ Quality of roads A1+ Quality of railroad infrastructure A2)/2

The comprehensive indicators of trade facilitation $(\mathrm{CC})=(\mathrm{KA}+\mathrm{TE}+\mathrm{LE}+\mathrm{DZ}+\mathrm{TC}) / 5$

Data calculated by later learned that within the ASEAN Trade Facilitation level uneven levels, such as Singapore trade facilitation within the overall score is much higher than other ASEAN countries.

\subsubsection{Model Establishment}

We introduce the standard model of international trade - the gravity model. And we set the gravity model is a natural loglinear form, the basic model is set as follows:

$\ln$ Trade $_{i j}=c_{0}+c_{1} \ln G D P_{j}+c_{2} \ln G D P_{j}+c_{3} \ln P G D P_{i}+c_{4} \ln P G D P_{j}+c_{5} \ln J L_{i j}+u_{i j}$

In this paper, we study between China and countries along the maritime Silk Road trade situation, selecting the section data of 2014 , according to our research purpose, the modified gravity model:

$$
\begin{aligned}
\ln \text { Trade }_{i j}= & c_{0}+c_{1} \ln G D P_{j}+c_{2} \ln P G D P_{j}+c_{3} \ln J L_{i j}+\alpha \ln C C_{j}+ \\
& c_{4} \ln T A R_{j}+c_{5} \text { POLICY }_{i j}+c_{6} B O R_{i j}+u_{i j}
\end{aligned}
$$

Compared with type(1), can be found as follows: First, we examine the trade between China and other countries, and therefore China's data is constant, there is no effect on the results of the regression model, the coefficient variable is 0 , can be removed from the model; Secondly, the trade facilitation comprehensive index into the model, indicating the bilateral trade environment, if Member States are members of the ChinaASEAN Free Trade Area, which takes a variable value, and 0 otherwise, and therefore, the variable is discrete variables; Finally, the former represents the average tariff $\mathrm{j}$ country, namely the average of all trade in goods tariff rates. Dummy variables, when its value is 1 when the show $j$ and the Chinese territory bordering the partner countries, if the value is 0 , indicating no border with the Chinese territory. Related to the specific meaning of the variables as shown in Table 1: The Description and Explanation of Symbol in this Paper in IV. The Description of Symbol.

\subsection{Application and Conclusion of Trade Evaluation Model in Maritime Silk Road}

5.2.1 Comprehensive Application and Improvement in Multivariate linear regression model and Trade Gravity Model

\section{The Basic Regression Model}

Using the least squares method, using SPSS 19.0 software basic model, the regression results in Table 3:

Table 3. Variable regression model results

\begin{tabular}{ccc}
\hline $\begin{array}{c}\text { Independent } \\
\text { variable }\end{array}$ & $\begin{array}{c}\text { Regression } \\
\text { Coefficients }\end{array}$ & T-Statistics \\
\hline C- & - & 0.925 \\
$\ln G D P$ & 0.943 & 0.006 \\
$\ln P G D P$ & 0.091 & 0.611 \\
$\ln J L$ & 0.073 & 0.729 \\
\hline
\end{tabular}

Note: According to the results of the regression SPSS 19.0 software finishing.

Available from the results, it is $0.887 ; \mathrm{F}=15.696, \mathrm{P}=0.003<$ 0.01 . Thus available, the explanatory power of the model is acceptable and relatively stable. GDP explanatory variables and regression coefficients of large absolute PGDP before, indicating the influence of the explanatory variables is large, but also through the $\mathrm{t}$ value judgment, these variables are significant.

\section{Gravitational regression model modification}

The trade facilitation index $\mathrm{CC}$ is introduced into the regression model, can be obtained in Table 4:

Table 4. Correction of regression results

\begin{tabular}{ccc}
\hline $\begin{array}{c}\text { Independent } \\
\text { variable }\end{array}$ & $\begin{array}{c}\text { Regression } \\
\text { Coefficients }\end{array}$ & T-Statistics \\
\hline C & & 0.041 \\
$\ln G D P$ & 0.415 & 0.854 \\
$\ln P G D P$ & -0.114 & -0.563 \\
$\ln J L$ & -0.120 & -0.501 \\
$\ln C C$ & 0.446 & 2.186 \\
$\ln T A R$ & -0.053 & 0.331 \\
POLICY & 0.288 & -0.600 \\
BOR & 0.011 & 0.060 \\
\hline
\end{tabular}

Available from the results, it is $0.982 ; \mathrm{F}=16.026, \mathrm{P}=0.006$ < 0.01 ,After the adoption of contrast Tables 3 and 4, the introduction of trade facilitation indicators, whether or value of $\mathrm{F}$ are improving, the explanatory power of the model described improved than before, And after analysis of explanatory variables, we found GDP is still the key variables that affect trade, but trade facilitation CC coefficient is 0.446.Description: trade facilitation indicators for each one percentage point to enhance the volume of trade will double, you can observe, before the tariff coefficient is negative, the reduction of tariffs 
to promote trade, but the effect is far less than trade facilitation has brought results.

\subsubsection{The impact of trade facilitation in the twenty-first Century Maritime Silk Road}

In order to analyze the impact of different trade facilitation measures on the trade volume, in order to make a more targeted policy recommendations, we have to amend the gravity model to join 5 trade facilitation indicators.

$$
\begin{aligned}
& \ln \text { Trade }_{i j}=c_{0}+c_{1} \ln G D P_{j}+c_{2} \ln P G D P_{j}+c_{3} \ln J L_{i j}+\alpha_{1} \ln K A_{j}+ \\
& c_{4} \ln T A R_{j}+c_{5} P O L I C Y_{i j}+c_{6} B O R_{i j}+u_{i j} \\
& \ln \text { Trade }_{i j}=c_{0}+c_{1} \ln G D P_{j}+c_{2} \ln P G D P_{j}+c_{3} \ln J L_{i j}+\alpha_{2} \ln T E_{j}+ \\
& c_{4} \ln T A R_{j}+c_{5} P O L I C Y_{i j}+c_{6} B O R_{i j}+u_{i j} \\
& \ln \text { Trade }_{i j}=c_{0}+c_{1} \ln G D P_{j}+c_{2} \ln P G D P_{j}+c_{3} \ln J L_{i j}+\alpha_{3} \ln L E_{j}+ \\
& c_{4} \ln T A R_{j}+c_{5} P O L I C Y_{i j}+c_{6} B O R_{i j}+u_{i j} \\
& \ln \text { Trade }_{i j}=c_{0}+c_{1} \ln G D P_{j}+c_{2} \ln P G D P_{j}+c_{3} \ln J L_{i j}+\alpha_{4} \ln D Z_{j}+ \\
& c_{4} \ln T A R_{j}+c_{5} P O L I C Y_{i j}+c_{6} B O R_{i j}+u_{i j} \\
& \ln \text { Trade }_{i j}=c_{0}+c_{1} \ln G D P_{j}+c_{2} \ln P G D P_{j}+c_{3} \ln J L_{i j}+\alpha_{5} \ln T C_{j}+ \\
& c_{4} \ln T A R_{j}+c_{5} P O L I C Y_{i j}+c_{6} B O R_{i j}+u_{i j}
\end{aligned}
$$

After correlation calculation, as shown in Table 5.

Table 5. Trade growth forecast after the implementation of trade facilitation $(\%)$

\begin{tabular}{llllll}
\hline $\begin{array}{l}\text { Economy } \\
\text { Group }\end{array}$ & KA & TE & LE & DZ & TC \\
\hline $\begin{array}{l}\text { Brunei } \\
\text { Darussalam }\end{array}$ & 28.85 & 5.58 & 8.71 & 16.48 & 9.47 \\
Malaysia & 10.12 & 44.89 & 21.04 & 28.87 & 14.01 \\
Philippines & 2.38 & 97.87 & 45.96 & 50.12 & 33.95 \\
Singapore & 11.96 & 5.78 & 8.94 & 18.02 & 9.87 \\
Thailand & 4.56 & 62.77 & 36.48 & 42.74 & 52.31 \\
India & 9.66 & 35.67 & 18.74 & 32.45 & 10.03 \\
Pakistan & 8.73 & 31.23 & 15.78 & 29.84 & 9.92 \\
Myanmar & 3.93 & 65.83 & 38.57 & 45.04 & 54.23 \\
Cambodia & 3.54 & 149.32 & 54.54 & 76.53 & 40.97 \\
Japan & 15.76 & 4.97 & 8.84 & 19.02 & 9.69 \\
\hline
\end{tabular}

The results show that the degree of trade facilitation is the highest and the space is not large. Philippines, Vietnam, Kampuchea will give priority to the customs and e-commerce applications can improve the trade volume.

From this we give the suggestion that in the domestic resources to improve the range of 5 points of trade facilitation, if the limited resources, it should be based on the relevant calculation, determine which trade facilitation of the contribution of the sub index, priority to the use of resources in a greater impact on the trade facilitation of points.

Specifically, governments should increase the investment in the infrastructure of trade facilitation, not only the construction of hardware facilities, but also the investment of software facilities. Second, the development of e-commerce, the relevant countries, especially ASEAN countries, in communication networks and big data processing is a serious short board, which greatly restricts the trade volume. Therefore, China and other countries should vigorously develop the Internet in accordance with their own national conditions, the implementation of government network, paperless office. Finally, we must improve the customs policies and regulations, strengthen the transparency of information and the overall service capacity of the customs.

Trade facilitation is the first proposed and studied by the developed countries in twenty-first Century, the maritime Silk Road strategy should be studied, the use of relevant knowledge, promote the "along the way" of economic and trade development, and enhance the confidence of the relevant countries.

\section{MODEL SUMMARY AND IMPROVEMENT}

With the improvement of living standards, network security has become a hot issue of social concern, with the help of the network, the activities of terrorist organizations have been greatly expanded.

\subsection{The advantage \& disadvantage of Trade Gravity Model}

Advantages:

1. Trade gravity model on the determinants of the bilateral trade flows has strong explanatory power and achieved great success in many applications. Most of the research shows that, whether from the trade as a whole, or only from the industry level, trade partner economies of scale (GDP), space distance, population and system arrangement are significant effect factors, especially the role of the economy. The role of the institutional arrangements for differences, mainly depends on the total member economies of scale.

2. With the development of the institutional economics, people are paying more attention to the formal system and informal system's impact on international trade flows. Many studies confirm that legal system of trade partners, contract implementation, security, property safety and other factors to a large extent affects the traders expectations about the safety of transaction, so the system is superior to bilateral trade flows has a prominent effect. In addition, the system of quality similar countries easier to build up trust, thus is advantageous to the bilateral trade.

Disadvantages:

Despite the gravity model of trade between the countries, and even trade creation has strong explanatory power, but for some trade phenomenon, gravity model is ragged.

1. Industry trade between the countries is zero, CES preference doesn't tally with the real data, the trade of income elasticity deviation unit elasticity and between the industry is not the same and not reasonable explanation.

2. Gravity model estimation method is easy to underestimate trade trade between countries, overestimate small volume of trade between nations. If included in the gravity model is specialized in primary products production and export of small, can bring interference to model, estimation and prediction results are inaccurate 
The reason is that small country's main export products more onefold, and mostly labor intensive products or natural products, gravity model is often include national income, the distance is no longer the main factors affecting these products trade. Gravity model, therefore, are often unable to trade goods single effective analysis of trade between nations.

3. When using the gravity model analysis to export problems also exist obvious malfunction.

\subsection{The advantage \& disadvantage of Data Classification Model}

Advantages:

1. Regression analysis based on the analysis of multifactor model, a more simple and convenient;

2. Using the regression model, as long as the same model and data, through the standard statistical method can calculate the only result;

3. Regression analysis can accurately measure the factors fitting degree of regression and correlation degree between high and low, improve the effect of prediction equations; Due to actual a variable in the regression analysis method is rarely influenced by individual factors, only pay attention to the mode of suitable range, so the multivariate regression analysis method is suitable for practical economic problems, comprehensive influence by various factors. Disadvantages:

4. In this model, it can be used to classify the data in the algorithm. So it is not possible to achieve the actual application. There will always be some errors.

Disadvantages:

Sometimes in regression analysis, choose what factor and the factor what expression is a kind of speculation, which affects the utilization factor of diversity and unpredictable, some factors regression analysis in some cases was limited.

\section{REFERENCES}

[1] Liu Jia. "The new Silk Road Economic Belt" strategy considerations [D]. Beijing Foreign Studies University, 2015.

[2] Hou Fulai. "The Belt and Road" under the national strategy China EU economic and trade relationship between [D]. China Foreign Affairs University, 2015.

[3] Fan Xiufeng, Cheng Wenxian. Study on trade facilitation of the new Silk Road on the sea [J]. International Business (Journal of University of International Business and Economics), 2015,05:144-152.

[4] Liang Feiran, new China's new child. Silk Road Economic Belt total factor productivity from the perspective of financial measure of [J]. Industrial Technology Economy, 2015,10:59-68.
[5] Ma Bo. "Along the way" and the "global maritime fulcrum" of strategic docking research [J]. International Outlook, 2015,06:33-50+152-153.

[6] Zhang Yong. The strategic significance of the construction of the Silk Road on the sea in twenty-first Century [J]. new economy, 2014,31:47-53.

[7] Li Xiangyang. The diversity and cooperation mechanism of the Silk Road on the sea [J]. world economy and politics, 2014,11:4-17+155.

[8] Wang Aihu. The value and significance of the development of the Silk Road from the sea to the value and significance of the new maritime Silk Road [J]. Journal of South China University of Technology (SOCIAL SCIENCE EDITION), 2015,01:1-14.

[9] Zhou Maorong, Tan Xiujie. The trade potential and its influencing factors of the Silk Road on the sea in twentyfirst Century, [J]. International trade issues, 2015,02:312.

[10] Zhao Yiqi, Wang Zhaoxin. The maritime Silk Road Economic Zone Tourism Service Industry in Hainan Province, an empirical study on the influence of regional economic [J]. Journal of Commercial College of Guizhou, 2015,02:36-40.

[11] Chen Wanling, He Chuantian, the parties to the maritime Silk Road and its economic and trade position [J]. Reform, 2014,03:74-83.

[12] Zhang Yong. A brief discussion on the national development strategy of the Silk Road on the sea in twenty-first Century [J]. Journal of Ocean University of China (SOCIAL SCIENCE EDITION), 2014,05:13-18.

[13] Quan Yi, Wang Jie, Liu Wanting. The strategic vision and construction strategy of the Silk Road on the sea in twenty-first Century [J]. International trade, 2014,08:415.

[14] Shan Na. Corporate environmental strategy decision [D]. study and performance evaluation of Ocean University of China, 2012.

[15] Peng Rongsheng. The connotation, mechanism and evaluation of regional economic coordinated development [D]. Henan University, 2007.

[16] Yao Li. Economic growth effect of regional economic integration [D]. Northeast Normal University, 2015.

[17] Feng Weijiang. International political and economic analysis of the Silk Road Economic Zone [J]. 2014,06:73-98+157-158.

[18] Zhang Yongfeng, Du Zhongchao. Analysis of the competitiveness of the 10 cities along the Silk Road in Northwest China [J]. Arid Zone Resources and Environment, 2009,10:194-200.

[19] Chen Xiuzhen - CDI. Quantitative economic integration between Hong Kong and the mainland open evaluation index of [J]. Review of the Degree of Economic Integration between Hong Kong and Mainland China, 2005,04:62-68.

[20] Bi Wei. Theory and practice of circular economy and the comprehensive evaluation system of [D]. Tianjin University, 2006. 